\title{
Is Social Media, Texting and Other Such Technology Hurting Our Interper- sonal Communication?
}

\section{Christa Arnold*}

Department of Communication, University of North Florida, USA

I love going out to eat with my family. Growing up dinner time was social time, the time where we all caught up on each other's days, shared our ups and downs, and discussed exciting topics that would occur on a daily basis. As I sat down with my husband and children at our favorite restaurant I was looking forward to finding out how everyone's day had gone and to just have some enjoyable family banter. However, as I looked around the table, all I saw were the tops of my family's heads, they were texting, playing games, and surfing the internet with their cell phones. My youngest daughter, who is 9 , had her tablet and was playing angry birds. Not a word was exchanged. I asked them a question, everyone held a finger up to me to hold me off for a few more minutes. I wanted to scream out in the restaurant "REALLY????" Your phones and tablet are more interesting than conversing with me? I actually felt dejected. What happened to face to face interpersonal conversation being something to look forward to? Am I really that old and out of touch? I like technology as much as the rest of the world, but at the dinner table? Is it necessary at all moments of free time? Could my kids even carry on a productive conversation with other adults? Why does my oldest son have to text me about what I am cooking for dinner when he is literally in the next room? Have they learned this skill known as interpersonal communication or do they just avoid face to face interactions with people that are not in the texting or facebook loop?

This is not just about my family, as I was teaching my upper division skills based Listening class, I was speaking to the fact that we can only truly listen to, attend to, and fully process one stimuli at a time particularly if that stimuli is auditory like my lecture. I then gave them a technique of how to avoid interruptions and be able to focus on specific stimuli's of importance. As I looked across the class, I saw heads down texting during this time, no surprise when I received emails from those that were texting that they needed notes on my lecture about listening to stimuli. I told them to come to my office hours and we would discuss the missing notes from class and I would explain the material and auditory exercise that they missed. Well, not one person ever showed up to my office hours. I suppose it was easier to text, email, facebook other students, have them scan the notes in an email or google doc together than come and have face to face conversation with the professor. Are we really so dependent on our technology that we have lost interest in the art and enjoyment of face to face interpersonal communication?

My argument is that while texting, facebook, and other social media are certainly social and counts as communication interaction, it is not truly the same as a face to face interpersonal conversation. Where is the paralanguage, the way the message is spoken? How do you detect tone, quality, inflection, and dynamics of the voice? What about body language? How did they look when you told them you couldn't meet them for dinner because something else better came up? How can we truly negotiate meaning if we are missing the nonverbal dimension of interpersonal communication? I know the emoticons are helpful, but are they enough to convey how we really feel emotionally? Sometimes I throw in an emoticon not because I was really laughing but the emoticon was just so cute!

Once I responded to a disgruntled student over a test grade trying to empathically explain why his grade was so low, my words were kind and understanding, however, I accidentally left my caps lock on and wrote my very therapeutic response in all caps. The student shot back another email saying "you didn't have to be so angry." I was stunned. I wrote such a nice understanding response to his test score so I asked him why he thought I was angry and he said I wrote all in caps. I guess the all caps trumped my nice and kind words in the email.

Call me old fashioned, out of touch, technologically declined, whatever you choose, but I miss conversing with my friends over coffee and instead they make me text for an hour. Even the phone call is becoming obsolete. I miss watching students laughing and engaging with each other as they change classes because while they may travel together, they are on their phones checking texts, sending texts, looking at email, or facebook updates, or many other media outlets available to them. I miss my family dinners because now every time the phone vibrates or rings, all members jump up to see who is contacting them even if it is mid conversation What happened to the art of conversation, to all the nonverbal perks of interpersonal face to face communication. What about our listening skills? Do we really listen comprehensively or do we pretend to pay attention wondering when the next text is coming or who just posted on your facebook wall.

Communication is an art form in all contexts including the written one. I just want to hang onto those wonderful interpersonal face to face moments a little longer. Maybe I should do as my teenage son says and "get with the times," but this old dog does not want to forget all her interpersonal, listening, and conversational tricks. Well, I better stop conversing as I just received a text message.

*Corresponding author: Christa Arnold, Department of Communication, University of North Florida, USA, Tel: (804) 827-3772; E-mail: christa.arnold@unf.edu

Received May 07, 2012; Accepted May 07, 2012; Published May 09, 2012

Citation: Arnold C (2012) Is Social Media, Texting and Other Such Technology Hurting Our Interpersonal Communication? J Mass Commun Journalism 2e120. doi:10.4172/2165-7912.1000e120

Copyright: (c) 2012 Arnold C. This is an open-access article distributed under the terms of the Creative Commons Attribution License, which permits unrestricted use, distribution, and reproduction in any medium, provided the original author and source are credited. 